\title{
Reclamation and management of polluted soils: options and case studies
}

\author{
Jaume Bech ${ }^{1}$ \\ Received: 29 January 2018 / Accepted: 30 January 2018 / Published online: 24 February 2018 \\ (C) Springer-Verlag GmbH Germany, part of Springer Nature 2018
}

\section{Background}

The collection of papers presented in this Special Issue is an outcome of the SSS8.2 Session "Reclamation and Management of Polluted Soils: Options and Case Studies" of the European Geosciences Union Conference held in Vienna, April 2016.

Soil is the essential base of the biosphere, limited and fragile resource of mankind, food and drinking water. Therefore, soil quality must be preserved. However, the nature of soils is often altered by mismanagement of industrial and mining activities, energy generation; the increase of traffic, overuse of agrochemicals, and waste disposal are causing worldwide concern, especially in relation to the food chain and human health. The management and reclamation of polluted soils are not easy. There is a growing interest in the development of sustainable new options of management and innovative technologies of reclamation. This Special Issue deals with new data about identification, site investigation, assessment, eco-friendly, and costefficient remediation, monitoring and adequate management of contaminated areas. The papers of this issue cover important aspects of fundamental and applied research and provide advances in relation to existing knowledge.

This Special Issue contains 25 papers written by authors from 18 countries: Australia, Austria, Chile, China, France, Germany, India, Italy, Japan, Jordan, Pakistan, Peru, Philippines, Poland, Portugal, Russia, Spain, and Turkey. This collection of papers is mainly focused on eight topics: (1) microbial and enzymatic activities, (2) mine soils, (3) soilplant interactions, (4) urban soils, (5) organic pollution, (6) sequential extraction, (7) radionuclides, and (8) pollution and soil properties.

Jaume Bech

jaumebechborras@gmail.com; jbech@ub.edu

1 Department of Plant Biology, Faculty of Biology, University of Barcelona, 08028 Barcelona, Spain

\section{Research topics}

\subsection{Microbial and enzymatic activities}

Wang et al. (2017) investigated the combined bioremediation of soil co-contaminated with $\mathrm{Cd}$ and endosulfan by Pleurotus eryngii and Coprinus comatus and the effects on the soil biochemical indicators and microbial counts of co-contaminated soils. The authors used pot experiments and sequential extraction procedure. The results indicated that the combined bioremediation exerted the best remediation effect for cocontaminated soils.

Campos et al. (2017) examined the effect that wood ashes may have on the soil microbial activity on the basis of the dehydrogenase activity and soil oxygen consumption. Different wood ashes proportions and time dependence have been used to make comparisons. The authors found that ashes coming from olive marc and vine shoots may affect positively the soil respiration and the fertility, if they are applied in moderate amounts.

Nadimi-Goki et al. (2017) investigated the enzyme dynamics in contaminated paddy soils under different cropping patterns (NE Italy). The authors monitored the effects of four crop rotation systems (rice-rice-rice: R-R-R, soya-rice-rice: S-R-R, fallow-rice: F-R and pea-soya-rice: P-S-R) on the activities of six important soil enzymes during rice growth. The results suggest that the activity of most enzymes decreases with the following order: drained soil >late water $\beta$ logging $>$ early waterlogging $>$ moist soil. The best rotation system for chitinase, leucine aminopeptidase, and $\beta$-glucosidase activity was R-R$\mathrm{R}$, while for arylsulfatase and phosphatase activities were the SR-R.

Rico Hernandez et al. (2017) analyzed the survival of Escherichia coli, total coliforms, and Salmonella spp. in a soil amended with urban sewage sludge due to its potential use in soil rehabilitation and to the risk of microbial pollution. The authors found that long periods of time reduce the risk from the presence of pathogens in soils, and the persistence 
may be closely related to the treatment of sewage sludge and the initial amount of microorganisms in the sewage sludge.

Rajput et al. (2017) explored in this review the possible toxic effect of various nanoparticles (NPs) on crops and microbial communities. The authors analyzed the major sources of NPs to the environment and their effects of metal-based NPs on the microbiota, plants, and human health. They found that the exposure of soil to nanoparticles causes a decrease in soil microbial biomass, enzymatic activity, and biological diversity.

\subsection{Mine soils}

Lebrun et al. (2017) evaluate the phytostabilization capacity of Salix viminalis to remediate an $\mathrm{As}$ and $\mathrm{Pb}$ highly contaminated mine technosol amended with biochar and assessed their particle size and dose application effects. The authors concluded that fine biochar particles allowed $S$. viminalis growth on the contaminated soil allowing this species to be used for technosol phytostabilization.

Lam et al. (2017) assessed the adaptive capacity of species Gazania rigens and Pelargonium hortorum in copper mine tailings in the Antofagasta Region (Chile) one of the most arid in the world. The bioconcentration factor demonstrated that both species act as excluders of $\mathrm{Fe}, \mathrm{Mn}, \mathrm{Pb}, \mathrm{Al}$, and $\mathrm{Zn}$. Also these species present characteristics of potential accumulators of $\mathrm{Cu}$.

Minkina et al. (2017a, b) studied of $\mathrm{Cu}^{2+}, \mathrm{Zn}^{2+}$, and $\mathrm{Pb}^{2+}$ forms by sequential fractionation in mine and smelter technosols in Karabash, Southern Urals, Russia. The results shown that the distributions of $\mathrm{Cu}, \mathrm{Zn}$, and $\mathrm{Pb}$ forms in these technosols are due to the composition of pollutants, the time of the contamination, and the buffer properties of the polydisperse system of soils and parent materials.

Romero-Baena et al. (2017) reviewed the role of mineralogy and geochemistry to assess the hazard of soil contamination by trace elements in three mining areas of Andalucia (South Spain): (1) Linares-La Carolina ( $\mathrm{Pb}-\mathrm{Zn}$ ores), (2) Riotinto (Iberian Pyrite Belt), and (3) Aznalcollar mines (Iberian Pyrite Belt). The authors found that the oxidation of pyrite releases As and heavy metals that can be sequestered by sulfate-arsenate or efflorescent sulfates. Iron oxy-hydroxides were more stable, and they retained the contaminants at oxidant conditions. $\mathrm{Cd}, \mathrm{Zn}$, and $\mathrm{Pb}$ tend to be adsorbed at high $\mathrm{pH}$, and As was adsorbed by clays and iron-oxy-hydroxides.

Pérez-Sirvent et al. (2017) assessed the potentially toxic elements (PTEs) contamination in mine soils from Portman Bay (SE Spain). The authors used selective chemical extraction of $\mathrm{Pb}, \mathrm{Cd}, \mathrm{Zn}, \mathrm{Cu}$, and $\mathrm{As}$ in order to evaluate the potential mobility of metals. The highest PTEs content were obtained in the oxidizing medium. The mineralogical composition and the degree of weathering are decisive on the PTEs mobility.

\subsection{Soil-plant interactions}

Neu et al. (2017) researched the trace elements bioavailability to Triticum aestivum and to the earthworm Dendrobaena veneta in a multi-element contaminated agricultural soil amended with drinking water treatment residues (WTR). The authors examined the use of WTR based on Fe and (hydro)oxides as a cost-effective solution in the immobilization of $\mathrm{Cd}, \mathrm{Pb}, \mathrm{Zn}$, and As. They found that a bioassay with key species prior to field application should be perceptive in situ stabilization options. They concluded that low-application rates of WTR improve biomass; higher rates involved risks.

Rafiq et al. (2017) compared the efficiency of EDTA and calcium in alleviating arsenic toxicity in Vicia faba. The authors performed two separate experiments: $V$. faba seedlings grown under As-hydroponic conditions and grown in Ascontaminated sand culture in presence and absence of EDTA and $\mathrm{CaCl}_{2}$. The results showed that EDTA and $\mathrm{Ca}$ greatly affect AS accumulation and toxicity to $V$. $f a b a$, and the effect varies greatly with their applied levels as well as type and age of plant organs.

Rocco et al. (2017) assessed the changes induced by 5 years of native plant revegetation in the chemical properties and mobility bioavailability of $\mathrm{Pb}$ and $\mathrm{Zn}$ pollutants of soil and post-washing sludges from an Italian brownfield. The authors used sequential extractions to fraccionate $\mathrm{Pb}$ and $\mathrm{Zn}$ forms. Plant ability to uptake metals was evaluated on Bituminaria bituminosa, Daucus carota, and Dactylis glomerata. After revegetation, the $\mathrm{pH}$ decreased, the organic carbon content increased and enhanced the solubility in water of metalcontaining compounds.

Liberati et al. (2017) researched a phyto-dehydratation of confined sludge as a sustainable approach for the management of polluted ponds. A mesocosm-scale trial was carried out to test the capacity of different helophyte species to reduce the excess of water in an artificial pond filled with oversaturated sludge. This phytotechnology can be a suitable strategy to manage excess of water in polluted ponds.

\subsection{Urban soils}

Rodriguez-Bocanegra et al. (2017) assessed the heavy metal tolerance in Brassica juncea and Solanum lycopersicum in an experimental-disturbed polluted soil. This soil was highly contaminated by $\mathrm{Cu}, \mathrm{Pb}$, and $\mathrm{Zn}$. The two plants had an ability to transport heavy metals from the roots to the shoots, especially for Zn. Great concentration of the studied metals, in the drainage water, after irrigation of plants was observed.

Kosheleva et al. (2017) investigated the conditions of the lateral migration of potentially toxic elements and identified the zones of their accumulation in soil catenas of ore mining landscapes in the cities of Zakamensk (Buryat Republic, Russia) and Erdenet (Mongolia) which are situated in the 
basin of the Selenga River. The authors used the catenary approach and the concept of lateral geochemical barriers and found an increased content of sand with $\mathrm{W}, \mathrm{Mo}, \mathrm{Cd}, \mathrm{Bi}, \mathrm{Pb}$, and $\mathrm{Sr}$ derived from the tailings by water erosion in Zakamensk and of silt particles windblown with V, Co, Sr, and As in Erdenet.

Tume et al. (2017) researched the potentially toxic elements in urban soils of Talcahuano, Chile. The authors determined the concentrations and background levels of $\mathrm{Ba}, \mathrm{Co}$, $\mathrm{Cr}, \mathrm{Mn}$, and Ni in soils of Talcahuano, assessed the level of contamination, and identified the natural or anthropogenic sources and the spatial distribution of pollutants. They found a moderate to considerable contamination in some soil samples.

\subsection{Organic pollutants}

The work of Falciglia et al. (2017a, b) dealing with modeling and preliminary technical, energy, and economic considerations for full scale in situ remediation of low-dielectric hydrocarbonpolluted soils by microwave heating (MWH) technique. The authors found that sandy soils are more penetrable by MW irradiation that clay ones. The soil MW penetrability was also observed to increase with decreasing the soil moisture. The comparison with other clean-up technologies shows that in situ MWH is a deliverable alternative to conventional techniques.

Sushkova et al. $(2017 \mathrm{a}, \mathrm{b})$ researched for the first time the features of accumulation, migration, and transformation of benzo[a]pyrene $(\mathrm{BaP})$ in soil-plant system by using a new ecologically friendly water extraction method. The authors found a constant of BaP semi-decomposition in chernozems of Rostov Region with different pollution levels and different values of bioaccumulation in plants.

Sushkova et al. (2017a, b) studied the influence of PAHS contamination on soil ecological status monitoring soils and natural grassy vegetation plots established at different distances from Novocherkassk Power Station (NPs). Significant correlations were found between PAHs content and enzymes activity in plots situated through the prevailing wind direction from NPs that is the main pollution source. It was found that contamination of soil by PAHs depends on the activity of all soil biological communities as well as the dehydrogenase and the phytotoxicity of soils.

\subsection{Sequential extraction}

Burachevskaya et al. (2017) compared two methods of sequential fractionation in the study of copper compounds in Haplic Chernozem under model experimental conditions. The authors found that the Tessier method is more suitable for the separation of the total technogenic components from contaminated soils. The Miller method is more informative at the determination of loosely bound HM compounds because of the use of weaker extractants.

Weber et al. (2017) assessed the contamination of podzols in a subalpine zone of Karkonosze Mountains, Sudetes, Poland. $\mathrm{Cu}, \mathrm{Pb}$, and $\mathrm{Zn}$ concentrations and the patterns of their sequential extraction are discussed in relation to the possible influence of air-borne industrial emissions and the stage of degradation of dwarf pine stands. The authors found a high concentration of $\mathrm{Pb}$ and $\mathrm{Zn}$ organically bound fraction probably caused by a long-distance transport of anthropogenic emissions. The high concentrations of $\mathrm{Pb}$ or other metals form in soils cannot be considered to have been the principal causes of the ecological disaster in the Karkonosze Mts.

\subsection{Radionuclides}

Falciglia et al. (2017a, b) assessed at lab scale the detection efficiency and minimum detectable activity of ${ }^{241} \mathrm{Am}$ and

${ }^{152} \mathrm{Eu}$ of contaminated soils by low-altitude Unmanned Aerial Vehicles equipped with small size $\gamma$-ray spectrometer. The authors conclude that all achievements and the calculated fitting parameters are useful preliminary data in the quantitative characterization of soil surface contamination and represent a valuable tool in knowing the soil surface $\gamma$-ray activity of ${ }^{241} \mathrm{Am}$ and ${ }^{152} \mathrm{Eu}$ for each given detected value.

Chizhikova et al. (2017) researched the regional specificity of radionuclide fixation in river basins due to soil petrology and mineralogy and its ecological significance. The authors collected alluvial soil samples in Yenisey (Central Siberia) and Iput (East European Plain) and studied of ${ }^{137} \mathrm{Cs}$ distribution in clay minerals. Specificity of local clay minerals as radionuclide sorbents should be of a particular ecological concern in relation to long-term exchange processes of the radioisotope including its transfer to food chains.

\subsection{Pollution and soil properties}

Minkina et al. (2017a, b) studied the effect of contamination with $\mathrm{Cu}, \mathrm{Zn}$, and $\mathrm{Pb}$ high rates on the physical properties and organic matter of Haplic Chernozem under model experimental conditions. The authors concluded that under conditions of model experiment, the contamination with high rates of $\mathrm{Cu}$, $\mathrm{Zn}$, and $\mathrm{Pb}$ leads to changes of the microaggregate distribution, the structural status, and the qualitative composition of organic matter.

\section{Conclusions}

The 25 papers described on the eight sections cover important aspects of fundamental and applied research in Soil Science and provide advances in relation to existing knowledge. 
Acknowledgements I would firstly like to thank the co-guest editors Prof. Dr. Elena Korobova (Vernadsky Institute of Geochemistry and Analitical Chemistry, Moscow, Russia), Prof. Dr. Maria Manuela Abreu (Universidade de Lisboa, Instituto Superior de Agronomia, Linking Landscape, Environment, Agriculture and Food Research Centre, LEAF, Lisboa, Portugal), Prof. Dr. Carmen Pérez-Sirvent (Faculty of Chemistry, University of Murcia, Murcia, Spain), Prof. Dr. Claudio Bini (Department of Environmental Sciences, University of Venice, Venice, Italy), Prof. Dr. Hyo-Taek Chon (Department of Energy, Resources Engineering, Seoul University, Seoul 151-744, South Korea) and Prof. Dr. Nuria Roca (Laboratory of Soil Science, Faculty of Biology, University of Barcelona, Barcelona, Spain) for their excellent collaboration. Also, I would like to thank the authors for their contributions and for their patience with the review process, as well as the reviewers for their observations. Their efforts have improved the quality of this Special Issue. The language and IT assistance of James Dove are greatly appreciated. I am also extremely grateful to Prof. Dr. Philip N. Owens and Prof. Dr.Zhihong Xu, Editors-in-Chief of the Journal of Soils and Sediments and to Moira Ledger, Editorial Manager, without whose knowledge and experience this Special Issue could not have been published.

\section{References}

Burachevskaya M, Minkina TM, Mandzhieva S, Bauer T, Chaplygin V, Sushkova S, Orlovic-Leko P, Mashtykova L, Rajput V (2017) Comparing two methods of sequential fractionation in the study of copper compounds in haplic chernozem under model experimental conditions. J Soils Sediments. https://doi.org/10.1007/ s11368-017-1711-7

Campos JA, Peco JD, De Toro JA, Moreno C, Amoròs JA, Moreno MM, Garcia-Noguero EM, Higueras P (2017) Approach to the potential usage of two wood ashes waste as soil amendments on the basis of the dehydrogenase activity and soil oxygen consumption. J Soils Sediments. https://doi.org/10.1007/s11368-017-1840-z

Chizhikova NP, Korobova EM, Linnik VG, Chechetko ES (2017) Regional specificity of radionuclide fixation in river basins due to soil petrology and mineralogy. J Soils Sediments. https://doi.org/10. 1007/s11368-017-1707-3

Falciglia PP, Biondi L, Catalano R, Immè G, Romano S, Vagliasindi FGA (2017a) Preliminary investigation for quali-quantitative characterization of soils contaminated with ${ }^{241} \mathrm{Am}$ and ${ }^{152} \mathrm{Eu}$ by low altitude unmanned aerial vehicles (UAVs) equipped with small size $\gamma$-ray spectrometer: detection efficiency and minimum detectable activity (MDA) concentration assessment. J Soils Sediments. https://doi.org/ 10.1007/s11368-017-1720-6

Falciglia PP, Scandura P, Vagliasindi FGA (2017b) Modelling and preliminary technical, energy and economic considerations for fullscale in situ remediation of low-dielectric hydrocarbon-polluted soils by microwave heating (MWH) technique. J Soils Sediments. https://doi.org/10.1007/s11368-017-1682-8

Kosheleva NE, Kasimov NS, Timofeev IV (2017) Potentially toxic elements in urban soil catenas of W-Mo (Zakamensk, Russia) and CuMo (Erdenet, Mongolia) mining areas. J Soils Sediments. https:// doi.org/10.1007/s11368-017-1897-8

Lam EJ, Gálvez ME, Cánovas M, Montofré I, Keith BF (2017) Assessment of the adaptive capacity of plant species in copper mine tailings in arid and semiarid environments. J Soils Sediments. https://doi.org/10.1007/s11368-017-1835-9

Lebrun M, Miard F, Nandillon R, Hattab-Hambli N, Scippa GS, Bourgerie S, Morabito D (2017) Eco-restoration of a mine technosol according to biochar particle size and dose application: study of soil physicochemical properties and phytostabilization capacities of Salix viminalis. J Soils Sediments. https://doi.org/10.1007/s11368-017-1763-8
Liberati D, Sconocchia P, Ricci A, Gigliotti G, Tacconi C, Grenni P, Tariciotti S, Caracciolo AB, Massacci A, Lagomarsino A, De Angelis P (2017) Phyto-dehydratation of confined sludge: a sustainable approach for the management of polluted ponds. J Soils Sediments. https://doi.org/10.1007/s11368-017-1808-z

Minkina T, Linnik V, Nevidomskaya D, Bauer T, Mandzhieva S, Khoroshavin V (2017a) Forms of $\mathrm{Cu}$ (II), Zn (II), and $\mathrm{Pb}$ (II) compounds in technogenically transformed soils adjacent to the Karabashmed copper smelter. J Soils Sediments. https://doi.org/10. 1007/s11368-017-1708-2

Minkina TM, Pinskii DL, Zamulina IV, Nevidomskaya DG, Gülser G, Mandzhieva SS, Bauer TV, Morozov IV, Sushkova SN, Kizilkaya R (2017b) Chemical contamination in upper horizon of Haplic Chernozem as a transformation factor of its physicochemical properties. J Soils Sediments. https://doi.org/10.1007/s11368-017-1713-5

Nadimi-Goki M, Bini C, Wahsha M, Kato Y, Fornasier F (2017) Enzyme dynamics in contaminated paddy soils under different cropping patterns (NE Italy). J Soils Sediments. https://doi.org/10.1007/s11368017-1830-1

Neu S, Müller I, Brackhage C, Galazka R, Siebielec G, Puschenreiter M, Dudel EG (2017) Trace elements bioavailability to Triticum aestivum and Dendrobaena veneta in a multielement-contaminated agricultural soil amended with drinking water treatment residues. J Soils Sediments. https://doi.org/10.1007/s11368-017-1741-1

Pérez-Sirvent C, García-Lorenzo ML, Hernández-Pérez C, MartínezSánchez MJ (2017) Assessment of potentially toxic element contamination in soils from Portman Bay (SE, Spain). J Soils Sediments. https://doi.org/10.1007/s11368-017-1756-7

Rafiq M, Shahid M, Shamshad S, Khalid S, Niazi NK, Abbas G, Saeed F, Ali M, Murtaza B (2017) A comparative study to evaluate efficiency of EDTA and calcium in alleviating arsenic toxicity to germinating and young Vicia faba L. seedlings. J Soils Sediments. https://doi.org/ 10.1007/s11368-017-1693-5

Rajput VD, Minkina T, Sushkova S, Tsitsuashvili V, Mandzhieva S, Gorovtsov A, Nevidomskyaya D, Gromakova N (2017) Effect of nanoparticles on crops and soil microbial communities. J Soils Sediments. https://doi.org/10.1007/s11368-017-1793-2

Rico Hernandez JR, Gómez-Lucas I, Navarro-Pedreño J, Jordan MM, Bech J, Nieto Asencio MN, Portell Iñiguez N (2017) Environmental consequences from the use of sewage sludge in soil restoration related to microbiological pollution. J Soils Sediments. https://doi.org/10.1007/s11368-017-1721-5

Rocco C, Agrelli D, Coppola I, González I, Adamo P (2017) Native plant colonization of brownfield soil and sludges: effects on substrate properties and pollutant mobility. J Soils Sediments. https://doi. org/10.1007/s11368-017-1850-x

Rodriguez-Bocanegra J, Roca N, Febrero A, Bort J (2017) Assessment of heavy metal tolerance in two plant species growing in experimental disturbed polluted urban soil. J Soils Sediments. https://doi.org/10. 1007/s11368-017-1666-8

Romero-Baena AJ, Gonzalez I, Galán E (2017) Soil pollution by mining activities in Andalusia (South Spain) - the role of mineralogy and geochemistry in three case studies. J Soils Sediments. https://doi. org/10.1007/s11368-017-1898-7

Sushkova SN, Minkina T, Deryabkina I, Mandzhieva S, Zamulina I, Bauer T, Vasilyeva G, Antonenko E, Rajput V (2017a) Influence of PAH contamination on soil ecological status. J Soils Sediments. https://doi.org/10.1007/s11368-017-1755-8

Sushkova S, Minkina T, Deryabkina MS, Zamulina I, Bauer T, Vasilyeva G, Antonenko E, Rajput V, Kizilkaya R (2017b) Features of accumulation, migration, and transformation of benzo[a]pyrene in soilplant system in a model condition of soil contamination. J Soils Sediments. https://doi.org/10.1007/s11368-016-1634-8

Tume P, Gonzalez E, King RW, Cuitiño L, Roca N, Bech J (2017) Distinguishing between natural and anthropogenic sources for 
potentially toxic elements in urban soils of Talcahuano, Chile. J Soils Sediments. https://doi.org/10.1007/s11368-017-1750-0

Wang Y, Zhang B, Chen NJ, Wang C, Feng S, Xu H (2017) Combined bioremediation of soil co-contaminated with cadmium and endosulfan by Pleurotus eryngii and Coprinus comatus. J Soils Sediments. https://doi.org/10.1007/s11368-017-1762-9
Weber J, Dradrach A, Karczewska A, Kocowicz A (2017) The distribution of sequentially extracted $\mathrm{cu}, \mathrm{Pb}$ and $\mathrm{Zn}$ fractions in Podzol profiles under dwarf pine of different stages of degradation in subalpine zone of Karkonosze Mts (central Europe). J Soils Sediments. https://doi.org/10.1007/s11368-017-1715-3 